\title{
India's financial globalisation
}

\author{
Ajay Shah and Ila Patnaik
}




\title{
IMF Working Paper
}

\author{
Research Department
}

\section{India's financial globalisation}

\section{Prepared by Ajay Shah and Ila Patnaik*}

Authorized for distribution by Prakash Loungani

January 2011

This Working Paper should not be reported as representing the views of the IMF. The views expressed in this Working Paper are those of the author(s) and do not necessarily represent those of the IMF or IMF policy. Working Papers describe research in progress by the author(s) and are published to elicit comments and to further debate.

India embarked on reintegration with the world economy in the early 1990s. At first, a certain limited opening took place emphasising equity flows by certain kinds of foreign investors. This opening has had myriad interesting implications in terms of both microeconomics and macroeconomics. A dynamic process of change in the economy and in economic policy then came about, with a co-evolution between the system of capital controls, macroeconomic policy, and the internationalisation of firms including the emergence of Indian multinationals. Through this process, de facto openness has risen sharply. De facto openness has implied a loss of monetary policy autonomy when exchange rate pegging was attempted. The exchange rate regime has evolved towards greater flexibility.

JEL Classification Numbers:F15, F23, F32, F36, G15.

Keywords: India, financial globalisation, capital controls, capital flows

Author’s E-Mail Address:ashah@imf.org; ipatnaik@imf.org

\footnotetext{
* Both authors are with the National Institute of Public Finance and Policy, New Delhi. This note was prepared as an entry titled 'India' in the forthcoming Encyclopedia of Financial Globalization, ed. Gerard Caprio, Elsevier. We are grateful to Stijn Claessens, Masahiko Takeda and Manmohan Singh for numerous useful suggestions and insights. Email addresses: ajayshah@mayin.org and ilapatnaik@gmail.com
} 


\section{Contents}

1 From autarky to reintegration 3

2 Empirical facts about reintegration 4

2.1 Composition of capital flows . . . . . . . . . . . . 6

2.2 Internationalisation of firms . . . . . . . . . . . 8

3 Foreign portfolio investment in the equity market 11

3.1 Concerns about herding behaviour . . . . . . . . . . . . . 13

4 The role of FDI $\quad 15$

4.1 Inbound FDI . . . . . . . . . . . . . . . . . . 15

$\begin{array}{lll}5 & \text { Foreign borrowing } & 18\end{array}$

6 Effectiveness of capital controls and the exchange rate regime 19

7 Domestic finance and international finance 24

8 Policy questions about capital controls and monetary policy 26 


\section{From autarky to reintegration}

India's integration into the world economy blossomed in the First Globalisation. The trade/GDP ratio rose from 1 to 2 per cent in 1800 to 20 per cent in 1914. In 1940, when India was under colonial rule, restrictions on international trade and capital mobility were imposed throughout the Sterling Area as wartime measures. India gained independence in 1947, but emphasised autarkic policies, with a marked closing of the economy in the 1960s and 1970s. By 1970, the trade/GDP ratio had dropped to 8 per cent.

By 1991, with experience and international comparisons for 44 years in hand, the intellectual and policy consensus shifted against autarky. India then embarked on reintegration into the world economy through trade and capital account liberalisation. By the mid 1990s, the trade/GDP ratio had got back to the 20 per cent value seen in 1914. Reintegration into the world economy took place on both the current account and on the capital account. The early initiatives in capital account decontrol were based on three ideas:

- It was believed that debt inflows and all outflows were dangerous; hence strong restrictions against debt inflows and all outflows were kept in place.

- It was believed that inflows into the equity market were beneficial, but only if they originated from certain kinds of investors. Thus investment vehicles such as pension funds and university endowment funds were considered good, while hedge funds and individuals were considered bad. Hence, a limited opening was undertaken, where certain kinds of 'foreign institutional investors' (FIIs) were able to register in India with the securities regulator, and then given substantial flexibility including the lack of quantitative restrictions.

- While the official rhetoric was in favour of FDI, the removal of capital controls against FDI was limited in many sectors. Deeper liberalisation of capital controls against FDI took place later.

This opening of the economy was a key element of India's growth acceleration of the early 1990s. The combination of these reforms of the capital account, and trade liberalisation, unleashed a complex dynamic of change in the economy and in economic policy.

In this setting, the analysis of India's reintegration into the world economy is usefully organised around the following key questions. What were the microeconomic and macroeconomic consequences of this partial opening? How 
did capital account and current account opening interact with each other? What dynamic of change was unleashed in the political economy through the map of interests of gainers and losers associated with this mechanism of opening the economy? How did de facto openness evolve in the following two decades? While the bulk of these questions remain unanswered research puzzles, there is clarity on some sub-components of this larger picture, which is sketched in the following sections.

\section{Empirical facts about reintegration}

Direct reductions in customs duties which were spread over the period from 1991 till 2003 led to a rapid and sharp rise in trade. Trade also grew in response to reductions in transactions costs of transportation, and to the emergence of tradeable services based on computer and telecommunications technologies. Combining these, gross flows on the current account, expressed as per cent of GDP, grew dramatically from 8 per cent in 1990, to 31 per cent in 2000 and 71 per cent in 2008.

In terms of de jure capital account restrictions, the Chinn-Ito measure, which measures whether there were any segment where restrictions were completely removed, showed no change at -1.13 through the entire period. Within each restricted segment and market many steps in liberalisation did take place. This reflects the fact that the Chinn-Ito methodology, which is based on the IMF AREAER data, tends to portray India as closed, given the bureaucratic procedures which encumber all aspects of the Indian capital account. The Chinn-Ito result - of an unchanged score of -1.13 through the period - is correct in a cross-sectional sense, in that India's capital account restrictions are more onerous than those used in most emerging markets. At the same time, in a time-series sense, India is significantly more open on a de jure basis in 2010 when compared with 1990, which is not shown by the ChinnIto measure.

The de facto capital account integration measured by the Lane and MilesiFerretti database showed little change from 1990 to 2000, with a gross investment position (excluding official reserves) growing from 30 per cent of GDP in 1990 to only 42 per cent of GDP in 2000. However, significant change was visible after that, with a value of 85 per cent in 2007 . This marked acceleration of capital account integration after roughly 2000 recurs repeatedly in the discussion ahead. 


\begin{tabular}{|c|c|c|c|c|c|c|c|c|}
\hline \multicolumn{9}{|c|}{ Five-year averages, percent to GDP } \\
\hline & Debt & Debt & Debt & FDI & FDI & & & \\
\hline Year & Aid & Non-aid & Total & Inward & Outward & Portfolio & Other & Total \\
\hline 1955 & 0.09 & & 0.09 & & & & -0.09 & -0.02 \\
\hline 1960 & 0.65 & & 0.65 & & & & 0.25 & 1.16 \\
\hline 1965 & 1.68 & & 1.68 & & & & 0.02 & 1.88 \\
\hline 1970 & 1.98 & & 1.98 & & & & -0.01 & 2.03 \\
\hline 1975 & 0.45 & 0.10 & 0.54 & & & & -0.08 & 0.63 \\
\hline 1980 & 1.02 & 0.15 & 1.16 & & & & -0.41 & 0.78 \\
\hline 1985 & 0.63 & 0.31 & 0.94 & & & & -0.10 & 1.56 \\
\hline 1990 & 0.75 & 0.62 & 1.37 & & & & 0.20 & 2.00 \\
\hline 1995 & 0.82 & 0.89 & 1.72 & 0.18 & & 0.55 & 0.41 & 2.65 \\
\hline 2000 & 0.26 & 0.99 & 1.24 & 0.72 & & 0.59 & 0.11 & 2.19 \\
\hline 2005 & -0.11 & 1.13 & 1.02 & 1.02 & -0.32 & 0.95 & 0.16 & 2.73 \\
\hline 2010 & 0.20 & 1.86 & 2.06 & 2.49 & -1.34 & 1.25 & 0.11 & 4.55 \\
\hline
\end{tabular}

Table 1: Composition of capital flows

The Lane and Milesi-Ferretti data understates capital account integration to the extent that economic agents engage in illegal capital account transactions, which appears to be a significant issue in India. There is some evidence of Indian residents holding significant assets outside the country, and evidence of a significant scale of misinvoicing on the trade account. While the literature has focused on evasion of customs duties as the rationale for misinvoicing, the Indian evidence shows no significant change in misinvoicing across a sharp reduction in customs duties. This suggests a role for misinvoicing in the evasion of capital controls.

\subsection{Composition of capital flows}

Table 1 shows the composition of capital flows. Each value shown in the table is expressed as per cent to GDP, and represents the average over the latest five years. As an example, the value for 1955 is the average of the five years leading up to 1954-55. In each column, the largest value is shown in boldface.

In the early years, international financial integration was dominated by official assistance. Aid amounted to 1.68 per cent of GDP in 1961-1965, and 1.98 per cent of GDP in 1966-1970. These accounted for the bulk of the net capital flows in these years. Aid declined steadily therafter, and shows negligible values after 1995, reflecting the onset of international financial integration through the private sector. 
Capital account decontrol took place in three phases. The first phase involved borrowing by the private sector, which was first visible in the five years ended 1975. This borrowing has risen steadily through this period, attaining a value of 1.86 per cent of GDP for 2006-2010. Since this rise went alongside a decline of aid, the rise in overall borrowing has appeared subdued: the total debt inflow of 2.06 per cent of GDP for 2006-2010 is similar to the value of 1.98 per cent of GDP for 1966-1970.

In the early 1990s India faced a balance of payment crisis. This crisis was followed by an IMF structural adjustment program, economic reforms and liberalisation of the trade and capital accounts. Policy makers were, however, very cautious about opening up the economy to debt flows. The experience of the BOP crises as well as the lessons learnt from other developing countries suggested that debt flows, especially short term debt flows could lead to BOP difficulties if the country faced macroeconomic imbalances and had an inflexible exchange rate. The emphasis was, therefore, on foreign investment - both FDI and portfolio investment. Even these were opened up slowly and a complex administrative system of capital controls remained in place. Within foreign investment, the attempt was to continue within the infant industry argument support for domestic industry. Consequently, while equity markets, which allowed foreign investors to invest in Indian companies in almost all sectors, were opened up to foreign investors, the foreign direct investment regime was liberalised very slowly, sector by sector.

The second phase of capital account decontrol thus involved inward flows of FDI and portfolio equity investment. Significant values for these first showed up for the 1991-1995 period. Both have grown strongly in the following years, with 2.49 per cent of GDP coming in through FDI and 1.25 per cent of GDP coming in through portfolio investment, in the 2006-2010 period.

The third phase of capital account decontrol involved giving permissions to Indian companies to do overseas FDI. This yielded significant outflows of 0.32 and 1.34 per cent of GDP in the 2001-2005 and 2006-2010 period. While there has been some easing of the rules about outbound investment by individuals, the magnitudes involved have been miniscule.

Overall, net capital inflows were at roughly 2 per cent of GDP or below this all the way to 1990. After this, net capital inflows have largely risen consistently to an average of 4.55 per cent of GDP in the 2006-2010 period. In all components other than aid, the largest values for net capital inflow (or outflow) are seen in the 2006-2010 period.

In summary, in terms of the distinction between portfolio flows and FDI, in 
India's case, capital account integration with the world economy was dominated by portfolio flows. FDI inflows remained small in the early period while portfolio flows took off. Much later, when FDI flows showed a sharp rise, two-thirds or more of these flows were accounted for by foreign private equity funds, who are financial investors, with decision making that is clearly linked to the stock market in terms of valuations and prospects of exit. Hence, the majority of what is reported as 'FDI inflows' into India actually reflects financial globalisation. India is thus unusual among emerging markets in having capital account integration dominated by the process of domestic firms accessing foreign capital through both portfolio investment into listed equity and investments into unlisted firms by private equity funds.

With both trade and capital account liberalisation, the opening of the economy has taken place gradually. As emphasised above, measures of trade and capital account integration showed subtantial change from roughly 2000 onwards. This reflected a combination of policy gradualism, and the numerous areas in which institutional change was required as a concomitant of opening the economy.

\subsection{Internationalisation of firms}

Firm internationalisation lies at the centre of India's engagement with financial globalisation. There is sharp evidence of internationalisation at the firm level. Five dimensions of internationalisation can be examined:

1. A firm could import, thus buying raw materials and/or capital goods from foreign providers;

2. A firm could export;

3. A firm could obtain equity capital from external sources;

4. A firm could obtain debt capital from external sources (whether localcurrency denominated or foreign-currency denominated);

5. A firm could expand overseas, thus placing foreign assets on its balance sheet.

In order to describe the extent of internationalisation of Indian firms, we define four categories:

None 0 percent

Low Between 0 percent and 10 percent 
Table 2: Internationalisation of India's listed firms

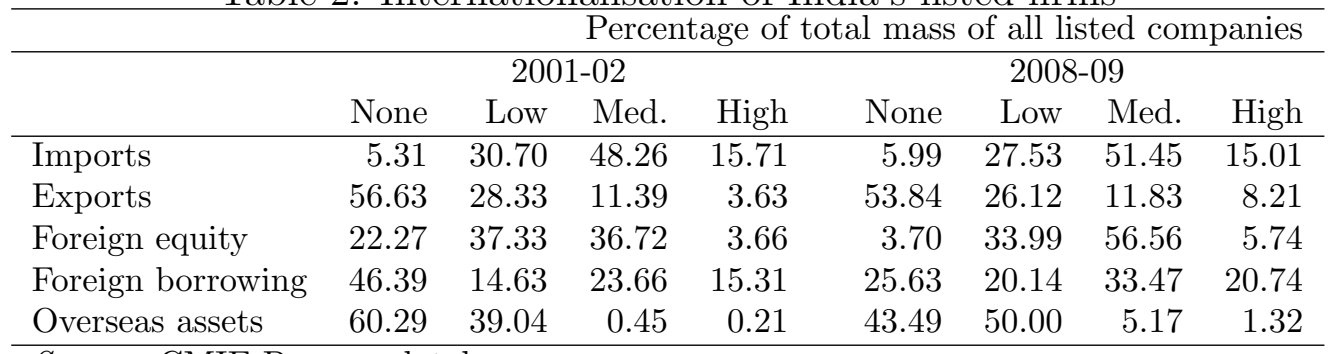

Source: CMIE Prowess database.

Medium Between 10 percent and 50 percent

High Above 50 percent

Using information from the CMIE database, we classify all large Indian firms into one of these four categories in all the four dimensions. ${ }^{1}$

Table 2 approaches internationalisation of Indian firms by reporting the fraction of aggregate firm size in each category. For our purposes, size is defined as the average of firm sales and total assets.

In 2001-02, 64 percent of total firms size involved corporations importing in the Medium or High categories. By 2008-09, this had risen to 66 per cent, a rise of 2 per cent. With exports, in 2001-02, 15 per cent of this mass was in either Medium or High. By 2008-09, the total firm size with export intensity in the Medium-High categories had risen to 20 per cent, a rise of 5 per cent. With both these trade-based measures, the change in international economic integration over this period was small. While the macroeconomic data on trade integration shows a sharp rise over this period, this data for large firms does not show a sharp change.

Large changes are, however, visible across this period with measures of financial internationalisation. In 2001-02, 40 per cent of the mass of Indian firms had either Medium or High equity investment. By 2008-09, this stood at 62 per cent: a sharp rise of 22 percentage points.

With foreign borrowing, in 2001-02, firms accounting for 39 per cent of the mass were in either Medium or High categories. In 2008-09, this had risen to 54 per cent - despite the stated policy of the government in aiming to deter debt inflows. Finally, with overseas assets, less than 1 per cent of Indian firms had either Medium or High overseas assets in 2001-02. By 2008-09,

\footnotetext{
${ }^{1}$ In 2001-02, there were 6,575 listed firms in India and in 2007-08 there were 6,268 listed firms.
} 
the number of Indian firms with Medium or High overseas assets had risen sharply to 6 per cent. Over half the mass of firms had non-zero outbound FDI.

A natural area of exploration lies in the interplay of internationalisation and financing constraints. An early literature found that the domestic financial system, and particularly the equity market, was sensitive to exporting status. Exporting firms faced reduced financing constraints. However, this evidence is based on the early 1990s, while the large changes in internationalisation of firm financing took place after 2000. These questions, hence, lie largely unexplored.

\section{Foreign portfolio investment in the equity market}

In the early 1990s, India opened investment into listed equities through the 'FII framework'. This involved the following key elements. Some, but not all, foreign investors were eligible to register with the Indian securities regulator (SEBI). Once registered, FIIs could buy shares in India without quantitative restrictions, or constraints on repatriation. No one FII was permitted to own more than 5 per cent of a firm, and there were weak restrictions on the ownership by all FIIs taken together.

One response of global financial firms to the Indian FII framework has been the rise of a market for 'participatory notes', which are OTC derivatives on Indian underlyings which are traded offshore. A handful of global firms are book-runners on this market. A foreigner who is not a registered FII with the Indian authorities is able to transact on the PN market. The bookrunners then hedge their net exposures of the book using the onshore market, to which they have access by virtue of being registered FIIs in India. One factor which has encouraged the use of PNs is the presence of transaction taxes on the onshore market, while PN transactions avoid these.

As the home bias literature has emphasised, there are many sources of home bias, and capital controls is only one element of these. In the event, when India embarked on a limited easing of capital controls against equity inflows, the home bias of foreign investors did not strongly change in response. Many other sources of home bias remained in place, including asymmetric information, capability of the domestic financial system, a limited number of listed firms of adequate size from the viewpoint of international investors, etc. 
The desire of policy makers to encourage foreign investors in the Indian equity market, in the early 1990s, helped in reopening long-standing policy questions about the equity market. Foreign investors faced many difficulties in accomplishing transactions in the Indian equity market. As an example, in August and September 1993, the settlement system (which was based on physical paper share certificates) found it difficult to handle the settlement volume of foreign investors. Similarly, foreign investors who sent orders to the open outcry trading floor of the Bombay Stock Exchange found an array of problems including high transactions costs and low probability of order execution.

A first response of many Indian firms was to issue in New York or London through GDRs and ADRs, thus using the institutional capability of these financial systems, and bypassing the infirmities of the domestic financial system. In the early 1990s, there was a sharp increase in this issuance.

When faced with similar conditions, many other developing countries have experienced a hollowing out of domestic financial intermediation. When a weak domestic financial system is difficult to reform for political reasons, domestic firms tend to interact with foreign investors in international financial centres like New York or London, leading to a shift in financial intermediation to offshore venues.

In the Indian case, from 1993 to 2001, the Ministry of Finance and SEBI led a strong reforms effort aiming at a fundamental transformation of the equity market. The changes on the equity market from December 1993 to June 2001 helped to increase liquidity, reduce risk, improve disclosure and increase the number of investors and trades in the market. These reforms led to a shift in the focus of foreign investors away from Indian securities traded in London or New York, and the primary markets for India-related equities trading became the NSE and BSE in Bombay.

These changes addressed one important source of home bias - the deficiencies of financial development in emerging markets - and were associated with a decline in home bias by foreign investors against investing in India. In 1991, the weight of Indian equities in the portfolio of international investors was zero. In the first decade of India's opening, this share rose to only 0.04 per cent, reflecting a largely unchanged extent of home bias against India. By 2007, there was a six-fold rise in this weight to 0.24 per cent, suggesting an easing (though not elimination) of home bias.

While India obtained significant financial development and capital account decontrol on the equity market, neither of these changes took place with the 
Table 3: Did FIIs exit en masse at times of domestic stress?

\begin{tabular}{lrrr} 
& \multicolumn{3}{c}{ Percent to mkt. capn. } \\
Event & $\mathrm{T}-1$ & $\mathrm{~T}$ & $\mathrm{~T}+1$ \\
\hline Parliament attack & -0.015 & 0.012 & -0.015 \\
$\quad$ 12-12-2001 & & & \\
Gujarat riots & 0.020 & 0.025 & -0.0001 \\
$\quad$ 27-02-2002 & & & \\
UPA government & -0.029 & -0.060 & -0.050 \\
$\quad$ 13-05-2004 & & & \\
$\begin{array}{l}\text { Mumbai attacks } \\
\text { 26-11-2008 }\end{array}$ & 0.015 & $\mathrm{NA}$ & 0.015 \\
\hline $\begin{array}{l}\text { Source: Sinha (2010) } \\
\text { Sorn }\end{array}$ & & & \\
\end{tabular}

bond market and banks. In the same period, firms undertook strong deleveraging through emphasis on equity financing: the debt-equity ratio of large non-financial firms dropped sharply from 1.7 in 1991 to 0.7 in 2007. There may be a causal relationship here: when firms faced greater financing constraints on bond- or bank-financing alongside reduced financing constraints for equity financing, they may have shifted in favour of greater equity financing. Consequently, while the share of foreign investors in equity rose sharply, in the bond markets it remained limited. Further there were regulatory caps on the stock of holdings of government bond by foreign investors. Corporate bonds were allowed to be held by foreign institutional investors only after 2004.

\subsection{Concerns about herding behaviour}

One major concern among policy circles has been of an en masse exit by a herd of foreign investors in a crisis. However, with thousands of foreign investors in India, there have been heterogeneous views, and in each crisis, some foreigners have been buying while others have been selling.

Table 3 shows information about net FII inflows on the equity market in four recent episodes of market stress. In each of them, relatively small values are seen for the net sales by FIIs. The largest values in the table involve net sales of 0.11 percent of market capitalisation on the event date (' $\mathrm{T}$ ') and the following day (' $\mathrm{T}+1$ ') associated with the formation of the UPA government in 2004. The scenario of massive sales by foreigners when India is experiencing difficulties does not fit the evidence we examined.

In the literature on financial globalisation and emerging markets, there have 
been concerns about the limited knowledge with foreign investors, which (in turn) leads to behaviour such as herding, sudden capital flow reversals, etc. In the Indian experience on the equity market, the behaviour of foreign investors has been benign.

The exploration of the factors underlying this difference is important. India's path in capital account liberalisation - with no quantitative restrictions, access to the Indian market for a large number of heterogeneous foreign investors, and with the ability of foreign securities firms to operate in Indian financial markets - has also been conducive to long-term investments by foreign financial firms in building teams which understand India. For a contrast, India's rules on foreign investment into rupee-denominated bonds are inimical to the construction of teams and knowledge among foreign investors.

The presence of thousands of heterogenous foreign investors of many kinds - ranging from pension funds to hedge funds - has helped shield the economy from the liquidity motivated orders emanating from any one group of investors in distress or facing correlated regulatory compulsions. The early opening of the capital account, where it was believed that only certain kinds of foreign investors should be permitted, induced homogeneity of foreign investors. However, incremental reform of capital controls has steadily increased the heterogeneity of the investor base.

The size and prominence of India in the world economy may have helped in giving foreign investors adequate incentives to obtain information and understanding about India. In these respects, India has a natural advantage in engaging with globalisation when compared with smaller countries.

\section{The role of FDI}

\subsection{Inbound FDI}

India opened up slowly to FDI in the 1990s. The limits on the share of foreign ownership was slowly increased in every sector. By 2000, while most sectors were open upto 100 percent, sectors where FDI was restricted include retail trading (except single brand product retailing), atomic energy, and betting. Table 4 shows the areas where FDI caps exist.

While inbound FDI investors have the ability to repatriate capital, so far, in the Indian experience, this reverse flow of capital has been tiny. As an 


\begin{tabular}{lr}
\hline Sector & Limit on foreign ownership (per cent) \\
\hline Areas where restrictions exist & \\
Airlines & 49 \\
Atomic minerals & 74 \\
Asset Reconstruction Companies & 49 \\
Banking & 74 \\
Broadcasting & 26 \\
Defence & 26 \\
Insurance & 49 \\
Investing companies in infrastructure & 26 \\
Petroleum refining & $26 / 100$ \\
Print media & $74 / 100$ \\
Telecom & 51 \\
Single brand retailing & 74 \\
Satellites establishment and operation & 100 \\
All other sectors &
\end{tabular}

Table 4: Sectoral FDI limits

\begin{tabular}{lrr}
\hline Country & $\begin{array}{r}\text { Value } \\
\text { (Billion USD) }\end{array}$ & $\begin{array}{r}\text { Share } \\
\text { (Per cent) }\end{array}$ \\
\hline Mauritius & 17.4 & 44.7 \\
USA & 3.8 & 9.9 \\
UK & 3.3 & 8.6 \\
Netherlands & 2.2 & 5.7 \\
Japan & 1.8 & 4.6 \\
Singapore & 1.7 & 4.3 \\
Germany & 1.3 & 3.3 \\
\hline Total (all countries) & 44.4 & 100 \\
\hline
\end{tabular}

Table 5: Country composition of FDI (April 2000 - August 2007)

example, in 2006-07, it was $0.01 \%$ of GDP. Hence, for all practical purposes, inbound FDI has been a one-way process of capital coming into the country.

When compared with other emerging markets, India has attracted relatively little FDI. The first phase of financial globalisation primarily involved Indian firms obtaining equity and debt capital from abroad, thus achieving a reduction in the cost of capital. This bolstered the competitive position of Indian firms competing against foreign companies producing in India through FDI and competing in global markets by exporting.

The easing of capital controls, coupled with strong investment opportunities in India, gave a strong rise in FDI flows into India: from $0.14 \%$ of GDP in $1992-93$ to $0.53 \%$ in $1999-2000$ and then to $2.34 \%$ of GDP in $2006-07$. 


\begin{tabular}{lrr}
\hline Sector & $\begin{array}{r}\text { Value } \\
\text { (Billion USD) }\end{array}$ & $\begin{array}{r}\text { Share } \\
\text { (Per cent) }\end{array}$ \\
\hline Services & 8.1 & 20.6 \\
Computer hardware and software & 6.2 & 16.0 \\
Telecom & 3.5 & 8.7 \\
Automobiles & 1.7 & 8.7 \\
Construction including roads & 2.1 & 5.2 \\
Electricity & 1.3 & 3.4 \\
\hline Total (all industries) & 44.4 & 100 \\
\hline
\end{tabular}

Table 6: Sectoral composition of inbound FDI (April 2000 - August 2007)

From April 2000 to August 2007, \$44 billion came into India through FDI. In terms of the country composition, the bulk of FDI into India came in from Mauritius: the reason for this is that India has a preferential tax treaty with Mauritius.

Services, financial and non-financial, attracted the highest amount of FDI. Between April 2000 to August 2007 USD 8 billion, or 20.6 percent of all FDI flows, came into the services sector. Next was computer software and hardware which attracted 16 percent of flows. Telecom (8.7\%), automobile industry $(8.7 \%)$, construction $(5.2 \%)$ and power $(3.4 \%)$ came next.

When FDI into India did rise significantly from 2002 onwards, as much as two-thirds of this FDI took the form of foreign private equity funds buying large stakes in Indian unlisted companies. This phenomenon can also be interpreted as foreign capital bolstering the competitive position of Indian firms competing against foreign companies producing in India through FDI.

This experience can be located in the debates about 'FDI as bad cholesterol' literature, where foreign portfolio investment is seen as a bigger accomplishment by an emerging market. FDI requires little institutional capability, while foreign portfolio investment requires high quality firms, domestic financial development, and capabilities in the legal and regulatory system.

\section{$5 \quad$ Foreign borrowing}

In the international literature and in policy thinking amongst emerging markets, the question of currency exposure has come to prominence. When the exchange rate regime gives out expectations of low currency risk, firms and governments are encouraged to borrow in foreign currency. Once currency mismatches are present, when large depreciations take place, this generates 
considerable distress.

Indian capital controls have been biased against foreign borrowing and particularly against short-dated foreign borrowing. This policy framework does not reflect an appreciation of issues of currency exposure. Strong restrictions are in place against FII investment in rupee-denominated bonds, while a much larger scale of offshore borrowing in foreign currency takes place. This policy framework has encouraged unhedged currency by firms, particularly in periods when the exchange rate regime involved greater pegging.

These issues came to prominence in 2008, when exchange rate volatility rose, a sharp depreciation took place, and the global credit market experienced turbulence. This had an adverse impact on the balance sheets of many Indian firms, particularly those which had borrowed abroad. The experiences of this period emphasised the weaknesses of India's policy positions on the three issues of original sin, the lack of development of the domestic bond market and the lack of development of a domestic banking system.

\section{Effectiveness of capital controls and the ex- change rate regime}

India has an elaborate system of administrative capital controls. Rules differ according to investor classes, the markets operated in and the assets bought or sold. This implies that capital controls involve a number of institutions and regulators. Apart from the Government of India, capital flows are regulated by the Reserve Bank of India, the Securities and Exchange Board of India, the Forward Markets Commission, the Insurance Regulatory and Development Authority, and the Pension Fund Regulatory and Development Authority. Within the Government of India, the Ministry of Finance deals with portfolio investment, and the Ministry of Commerce with foreign direct investment policy.

The legal powers to regulate capital flows also emanate from a number of laws. Capital flows are regulated by the Reserve Bank of India under the powers it has through the Foreign Exchange Management Act, 1999. Reserve Bank of India is authorized to manage transactions and capital flows in consultation with the Ministry of Finance. In addition, the Banking Regulation Act, 1949, and the Reserve Bank of India Act, 1934 and Reserve Bank of India Amendment Act of 2006 which also provide the Reserve Bank of India with the authority to regulate capital flows. 
The Acts then work through regulations, circulars and clarifications. One, the Reserve Bank of India articulates policy with regard to capital account transactions through regulations. These must be placed before Parliament. Further there are notifications. These require publication in the official gazette. In addition the Reserve Bank of India issues circulars, master circulars and clarifications.

The critical question in this field is: Are India's capital controls sufficiently onerous and sufficiently effective to give monetary policy autonomy alongside exchange rate pegging? Or does the pursuit of pegging set off distortions of monetary policy, which could then force a shift away from pegging?

Across time, three factors are giving greater de facto openness: the gradual pace of de jure capital account liberalisation, the increasing sophistication of firms including their conversion into multinationals, and the increasing capability of the domestic financial system through which financial engineering can be undertaken to bypass capital controls. As an example, positions on equities and options can be combined to achieve synthetic corporate bonds, thus frustrating capital controls against debt positions.

Some evidence using firm data suggests that the effectiveness of the capital controls is relatively limited. The first dimension of this evidence lies in the exchange rate exposure of firms. Capital controls in India have strong restrictions against dollar-denominated borrowing. If these controls were effective, firms should not be able to take on substantial currency exposure. However, the analysis of the currency exposure of firms shows firms were able to take on and lay off substantial exposures to the dollar (in response to the extent of exchange rate pegging). This suggests that the effectiveness of capital controls against dollar denominated borrowing was limited.

The second dimension of this is the episode where Lehman failed in September 2008. Indian capital controls do not allow firms to take foreign currency loans of maturity less than 3 years. Under a null hypothesis that India's de jure capital controls were fully effective, India should have been quite disconnected from the global crisis, given that firms were prohibited from engaging in short-term foreign borrowing. However, in the event, the Indian money market was thrown into turmoil, and the operating procedures of monetary policy broke down, despite a modest 1\% of GDP of an exit by foreign portfolio investors in the immediate aftermath of the Lehman default.

The third dimension of this lies in the analysis of the onshore premium on currency forwards compared with that seen abroad on the NDF market. Over the years, mispricings between these have been arbitraged away more 


\begin{tabular}{lllrrrrrr}
\hline & Start & End & $R^{2}$ & USD & EUR & GBP & JPY & Variance \\
\hline 1 & 11 Jan '91 & 28 Jan '94 & 0.84 & 0.94 & 0.01 & -0.01 & -0.05 & 0.45 \\
& & & $(19.52)$ & $(0.12)$ & $(-0.11)$ & $(-1.03)$ & \\
2 & 4 Feb '94 & 24 Feb '95 & \multirow{2}{*}{1.00} & 1.01 & -0.08 & -0.02 & 0.02 & 0.01 \\
& & & $(77.35)$ & $(-3.14)$ & $(-1.11)$ & $(1.79)$ & \\
3 & 3 Mar '95 & 21 Aug '98 & 0.71 & 0.85 & 0.08 & -0.00 & 0.08 & 0.52 \\
& & & & $(13.22)$ & $(0.68)$ & $(-0.04)$ & $(2.08)$ & \\
4 & 28 Aug '98 & 19 Mar '04 & 0.97 & 0.98 & 0.09 & -0.01 & 0.01 & 0.06 \\
& & & $(67.30)$ & $(3.52)$ & $(-0.59)$ & $(1.32)$ & \\
5 & 26 Mar '04 & \multirow{2}{*}{ 16 Mar '07 } & 0.86 & 0.75 & 0.23 & 0.09 & 0.23 & 0.24 \\
& & & & $(18.85)$ & $(2.04)$ & $(1.73)$ & $(5.46)$ & \\
6 & 23 Mar '07 & \multirow{2}{*}{ 25 Dec '09 } & \multirow{2}{*}{0.62} & 0.73 & 0.34 & 0.04 & -0.12 & 0.87 \\
& & & $(9.72)$ & $(3.06)$ & $(0.66)$ & $(-2.31)$ & \\
\hline
\end{tabular}

Table 7: Evolution of the Indian exchange rate regime

effectively, suggesting increasing de facto openness.

To the extent that capital controls are not effective, when monetary policy pursues a pegged exchange rate, significant distortions of monetary policy should build up. Hence, we examine structural change of the Indian exchange rate regime.

The rupee dollar exchange rate was administered by the RBI till 1993. After that the de jure exchange rate regime was declared a managed float. However, de facto currency regime was a peg to the US dollar. Details of the exchange rate regime can be seen in Table 7 . This reports estimation results of the exchange rate regression, where a numeraire (the Swiss franc) is chosen. The regression explains weekly percentage changes in the rupee-franc rate, and the explanatory variables are weekly percentage changes of the USD/CHF rate, the $\mathrm{EUR} / \mathrm{CHF}$ rate, the GBP/CHF rate and the JPY/CHF rate. These parameter estimates show how tight the USD peg was. If there is pegging to the USD, then fluctuations in the GBP, JPY and EUR will be irrelevant, and we will observe $\beta_{3}=\beta_{4}=\beta_{5}=0$ while $\beta_{2}=1$. The coefficient reveals the tightness of the peg to the USD. The $R^{2}$ of this regression shows the degree of flexibility. Values near 1 suggest lower exchange rate flexibility.

Structural change econometrics is used to identify dates of structural change. Hence, Table 7 shows the evolution of the exchange rate regime.

In Period 1, which started in January 1991, the only significant coefficient in Period 1 was that of the USD, and there was high inflexibility with an $R^{2}$ of 0.84. After an IMF program, India embarked on a reform of the exchange rate 
regime, to a 'market determined exchange rate'. In Period 2, the $R^{2}$ actually went to 1.0, showing a shift to a fixed rate. The implementation of the exchange rate regime in Period 2, which involved unsterilised intervention, was associated with significant monetary policy distortions and helped kick off an upsurge in inflation.

The first experience with flexibility came in Period 3, in the Asian crisis, where the $R^{2}$ dropped to 0.71 . In this period, there was a small Yen coefficient but the focus remained the US dollar. In January 1998, an interest rate defence of the exchange rate was mounted, with a 200 bps rise in the short rate despite weak business cycle conditions.

Once the Asian crisis subsided, pegging to the dollar recommenced with an $R^{2}$ of 0.97 in Period 4. This was a period of sterilised intervention, where large purchases of dollars were accompanied by sale of government bonds. In December 2003, the stock of domestic government bonds was exhausted, and this period soon come to an end.

Slighly greater flexibility came about in Period 5, with an $R^{2}$ of 0.86 . In this period, an unprecedented scale of currency intervention was accompanied by only partial sterilisation. This kicked off the largest ever credit boom in Indian history.

Finally, Period 6 shows the largest ever flexibility in the history of India's exchange rate regime, with an $R^{2}$ of 0.62 . This reflects a combination of unusual turbulence in 2008, and a reduced scale of intervention by the central bank.

If Indian capital controls were effective and India was largely closed on the capital account, this complex interplay between the exchange rate regime and monetary policy autonomy would not have arisen. India would have been able to pursue exchange rate pegging without attendant distortions of monetary policy. However, as this evidence shows, the pursuit of pegging has repeatedly induced substantial monetary policy distortions. Two periods of near-fixed rates stand out: Period 2 and Period 4. After the end of Period 4 in 2004, there has been significant movement towards greater exchange rate flexibility. This is consistent with an environment of relatively ineffective capital controls, and significant de facto openness.

The 'Bretton-Woods II' hypothesis predicts that countries like India should pursue exchange rate mercantalism with central banks building up foreign exchange reserves so as to undervalue the exchange rate. In the 19 years of experience summarised in Table 7, there are two periods where India's behaviour fit these predictions: Period 2 (1 year) and Period 4 (5.5 years). 
These add up to a third of India's experience. The Indian case, hence, does not support the Bretton Woods II proposition, that exchange rate undervaluation through currency intervention is a stable and sustainable solution for developing countries.

\section{Domestic finance and international finance}

Some emerging markets have experienced a significant shift of financial market activity to international financial centres. By and large, this has not taken place in India.

In the equity market, for a handful of ADRs, liquidity in the US exceeds that found in India. In certain kinds of OTC interest rate derivatives, the offshore market is bigger than the onshore market. Looking across the financial system, the domestic financial system is the dominant venue, apart from two exceptions (some kinds of OTC interest rate derivatives and a few ADRs).

Bombay is also starting to become an international financial centre in some respects. Some elements of financial services production by global firms is being done in India (mostly in Bombay) through offshoring. A first 'Indian Depository Receipt' listing has taken place.

Improvements in domestic financial development, and in the capabilities of domestic financial regulation, are likely to induce a stronger position for domestic financial intermediation and for Bombay as an international financial centre. In addition, three key factors will shape this evolution: increased de facto openness, domestic home bias and the tax treatment of international finance.

Domestic financial intermediation has held its ground owing to successful financial development in some areas. However, one factor which has assisted this is the system of capital controls. As an example, onshore customers of index futures are forced to use the onshore Nifty futures, and are unable to send orders abroad (to either the SGX-traded or the CME-traded futures on Nifty). Increased de facto openness will reduce the extent to which the domestic financial system enjoys this protectionist advantage. If changes in de facto openness are large, and progress on domestic financial development are weak, then a hollowing out of domestic financial intermediation could arise, as has taken place with many other countries.

A second key element of this lies in tax treatment of international finance. 
The Indian tax regime on these questions involves two key elements. First, there is a source-based tax treatment including a securities transactions tax. Second, once foreign investors route their investments into India through Mauritius, they get a residence-based treatment (i.e. exemption of taxation of non-residents) except for the securities transaction tax.

Source-based taxation is inimical to onshore financial intermediation. When India imposes taxes on non-resident financial activity in India, non-residents have an incentive to send orders on India-related contracts to venues such as Singapore, London and New York, all of which have residence-based taxation. Hence, until India gets to a framework of residence-based taxation, and particularly if India removes or modifies the Mauritius tax treaty, there is a risk of a hollowing out of domestic financial intermediation.

The third key element lies in domestic home bias. The portfolios of Indian residents and Indian portfolio managers are strongly tilted in favour of India. This reflects a combination of information asymmetries and capital controls. Banks, pension funds and insurance companies have no international diversification. To the extent that this home bias is alleviated, the large flow of Indian savings could attract international issuers. This could bolster onshore financial intermediation through issuance of shares and bonds in India.

In summary, so far, domestic financial intermediation has held up well, except for a handful of ADRs and some kinds of OTC interest rate derivatives, where an offshore market has greater liquidity than the onshore market. Bombay is in the early stages of becoming an international financial centre, through the traditional route (e.g. equity issuance by global companies in Bombay) and through a new and non-traditional route (some parts of global financial services production taking place in Bombay). But these relationships between domestic finance and international finance could fluctuate based on the four factors:

1. The extent to which domestic financial regulation improves, which would attract onshore activity,

2. Offshore finance will be able to better compete with onshore finance owing to deepening de facto openness. Hence, onshore finance will lose ground unless domestic financial regulation improves.

3. The extent to which India is able to shift to a residence-based framework for taxation, which is essential for ensuring that foreign order flow comes to India, and

4. The extent to which the home bias of Indian portfolios is diminished, 
which would help to attract international securities issuance in India.

\section{Policy questions about capital controls and monetary policy}

India has evolved a complex system of capital controls. If a single capital controls manual were released by the government, it would run to thousands of pages of detailed rules. As in other areas of public policy, complex and detailed systems of rules have many problems.

The first concern lies in the extent to which the rule makers are omniscient. As an example, India's positions on foreign borrowing are out of touch with contemporary economic thinking in terms of blocking the onshore rupeedenominated bond market in favour of offshore foreign-currency borrowing. Many other microeconomic distortions are visible, where a sophisticated private sector maximises given the ruleset, giving unintended consequences in the form of microeconomic distortions.

The second issue is the transactions costs associated with capital controls. Bureaucrats, lawyers and accountants lead to an increased time and cost of undertaking transactions when compared with that seen in a simpler system. Reforms which remove these deadweight costs would give benefits. In addition, in the optimisation of the private sector, these fixed costs are justified for large transactions but not for small transactions. Hence, the Indian system of capital controls is biased in favour of giving large firms greater access to the international financial system.

Third, there is more de facto openness than meets the eye. While India appears largely closed at first, the ingenuity of financial engineering coupled with legal engineering implies that for a sufficiently large expenditure of time and fees, many transactions are feasible. If India were largely closed, then the pursuit of exchange rate pegging would not have induced large monetary policy distortions. If India were largely closed, the failure of Lehman would not have triggered off a breakdown of the operating procedures of Indian monetary policy, despite a lack of exit by foreign investors.

These three issues will shape the policy analysis of the Indian system of capital controls. The second important group of policy questions concerns monetary policy. As India's capital account openness has deepened, the pursuit of exchange rate pegging would imply an increased loss of control of 
monetary policy. In response to this, exchange rate flexibility has risen, with the $R^{2}$ of the Frankel-Wei regression going down from 1.0 in Period 2 to 0.62 in Period 6.

However, all the changes of the exchange rate regime shown in Table 7 other than Period 2 were made without announcement by the central bank. This raises questions about the goals and operational procedures of monetary policy. What public statements would be made about the exchange rate regime? Since a floating exchange rate is not a monetary policy regime, what is the best use of the lever of monetary policy, once autonomy has been regained through shifting away from exchange rate pegging? What framework for accountability and transparency should be employed for the central bank, once the central bank is not held accountable for achieving an exchange rate target? If monetary policy clearly moves away from the pursuit of exchange rate pegging, then would this clear the decks for simplification of the system of capital account restrictions, and de jure openness? 


\section{References}

Echeverri-Gent, J. (2007): "Politics of market microstructure," in India's Economic Transition: The Politics of Reform, ed. by R. Mukherji, chap. 11. Oxford University Press, New Delhi.

LAhiRI, A. K. (2009): "Indian financial reforms: National priorities amidst an international crisis," Purushotamdas Thakurdas Memorial Lecture, ADB.

Lane, P. R., And S. L. Schmukler (2007): "The international financial integration of China and India," Discussion Paper 4132, World Bank.

Mistry, P. (2007): "Making Mumbai an International Financial Centre," Committee report, Sage Publishing and Ministry of Finance, Government of India.

OurA, H. (2008): "Financial development and growth in India: A growing tiger in a cage?," Discussion Paper 08/79, IMF.

PATnAiK, I. (2005): "India's experience with a pegged exchange rate," in The India Policy Forum 2004, ed. by S. Bery, B. Bosworth, and A. Panagariya, pp. 189-226. Brookings Institution Press and NCAER.

Patnaik, I., And A. Shah (2009-10): "Why India choked when Lehman broke," India Policy Forum, 6.

Patnaik, I., A. Shah, A. Sethy, and V. Balasubramaniam (2011): "The exchange rate regime in Asia: From crisis to crisis," International Review of Economics and Finance, 20(1), 32-43.

Pradhan, J. (2004): "The determinants of outward foreign direct investment: a firm-level analysis of Indian manufacturing," Oxford Development Studies, 32(4), 619-639.

Prasad, E. S. (2009): "Some new perspectives on India's approach to capital account liberalisation," Discussion Paper 14658, NBER.

Rajan, R. (2008): "Committee for Financial Sector Reforms," Committee report, Planning Commission, Government of India.

Shah, A., And I. PATnaik (2007): "India's experience with capital flows: The elusive quest for a sustainable current account deficit," in Capital controls and capital flows in emerging economies: Policies, practices and consequences, ed. by S. Edwards, chap. 13, pp. 609-643. The University of Chicago Press. 
Shah, A., S. Thomas, and M. Gorham (2008): India's Financial Markets: An Insider's Guide to How the Markets Work. Elsevier.

SinHA, U. K. (2010): "Working Group on Foreign Investment," Committee report, Department of Economic Affairs, Ministry of Finance.

Thomas, S. (2006): "How the financial sector in India was reformed," in Documenting reforms: Case studies from India, ed. by S. Narayan, pp. 171-210. Macmillan India, New Delhi. 